\title{
La praxis teatral y lo político: la demanda, el teatrista, el público
}

\section{(7) Gustavo Geirola}

Whittier College, Los Angeles, California, USA

gustavo.geirola@gmail.com

Fecha de recepción: 21/12/2018. Fecha de aceptación: 30/03/2019.

Para Antonio Prieto, por tantos años de amistad.

\section{Resumen}

El ensayo aborda las cuestiones de la praxis teatral desde lo que hoy se ha dado en llamar política lacaniana (Jacques-Alain Miller) e izquierda lacaniana (Jorge Alemán, Ernesto Laclau y otros). Se plantea la posición del teatrista durante el proceso de ensayos y montaje, siguiendo los aportes de Lacan sobre el acto analítico y sus consecuencias éticas. Al orientar la praxis teatral hacia un teatro de la emancipación y desde la perspectiva del acto performativo, se hace necesario revisar el concepto de la demanda (tanto del teatrista como del público), el rol político de lo heterogéneo como freno al progresivo incremento de lo homogéneo en la sociedad neoliberal. De ahí que la discusión sobre la oposición masa-pueblo, tal como la ha planteado Laclau, exija una revisión de la noción de convivio planteada por Jorge Dubatti. El resultado es una conceptualización de la praxis teatral -basada en el deseo, el sujeto del inconsciente y el saber-como un campo de intervención sostenido en la creatividad artística y dirigida a lo 'inapropiable' por el sistema capitalista. Así, la praxis teatral se posiciona fuera de los protocolos epistemológicos académicos orientados a la producción de conocimiento, apoyados en la reproductibilidad de la experiencia y el oficio, y centrados en el sujeto cartesiano, tal como lo plantean los estudios teatrales o la filosofía del teatro.

\section{Theatrical Praxis and the Political: Demand, Teatristas, Audience}

\begin{abstract}
The essay addresses the issues of theatrical praxis from what is now called Lacanian politics (Jacques-Alain Miller) and Lacanian left (Jorge Alemán, Ernesto Laclau and others). The position of the playwright is considered during the process of rehearsals and mise-en-scène, following the contributions of Lacan on the analytical act and its ethical consequences. By orienting the theatrical praxis towards a theater
\end{abstract}

Palabras claves

praxis teatral emancipación Lacan acto performativo convivio

Keywords

theatrical praxis emancipation Lacan performative act convivial 
of emancipation and from the perspective of the performative act, it is necessary to review the concept of demand (both the artist's and the audience's), the political role of the heterogeneous as a brake on the progressive increase of homogeneity in neoliberal society. Hence, the discussion on the mass-people opposition, as Laclau has proposed, requires a revision of the notion of conviviality raised by Jorge Dubatti. The result is a conceptualization of the theatrical praxis - based on desire, the subject of the unconscious and knowledge - as a field of intervention sustained in artistic creativity and directed at what remains 'inappropriate' by the capitalist system. Thus, the theatrical praxis is positioned outside the academic epistemological protocols oriented to the production of knowledge, supported by the reproducibility of experience and craft, and centered on the Cartesian subject, as proposed by theater studies or the philosophy of theater.

\section{Introducción}

La praxis teatral, dirigida a conceptualizar el saber-hacer del teatrista durante el proceso de montaje, es la disciplina involucrada en la creatividad artística. Por ello, la cuestión de tratar lo real mediante lo simbólico a fin de inventar un imaginario capaz de significantizar ese real -sufrido como malestar en la cultura- no puede estar alejada, debido a estas coincidencias, del psicoanálisis. Y el psicoanálisis debe ser entendido aquí, tal como Lacan lo planteara en la famosa Proposición del 9 de octubre de 1967 (en adelante "P67"), como una "experiencia original" (264) que, debido al descubrimiento freudiano del inconsciente, ha replanteado -si no subvertidotodos los protocolos ligados al saber y al conocimiento, a la posición del sujeto más allá del yo cartesiano y de la conciencia; por eso, tal como lo dice en ese mismo texto, "esta experiencia es esencial para aislarlo de la terapéutica" (P67: 264). De alguna manera ya venía Lacan enfatizando esta cuestión desde 1958 cuando, en "La dirección de la cura y los principios de su poder" (en adelante, "LD"), aunque todavía mantiene el término cura, ya advertía que "[d]ecir que la doctrina freudiana es una psicología es un equívoco grosero" (LD: 593). De modo que no hay aquí ningún planteo ligado a psicoanalizar a los teatristas y, mucho menos, curarlos, porque si hay algo que Lacan ya estableció para el psicoanálisis al final de su enseñanza, en el Seminario 23 El sinthome, es que se trata de un abordaje a lo incurable del sujeto, que él designó como el sinthome, su singularidad, su modo de gozar, con el que tiene que saber arreglárselas/saber-hacer responsablemente, lo cual supone un acto ${ }^{1}$ con base en la ética.

En tanto el teatro supone situaciones convenidas entre actores, entre actor y director, entre escena y público, sus lazos con el psicoanálisis no parecen ser forzados. Menos aun cuando ya Freud designaba al inconsciente como "la otra escena". Y si bien, como en el caso analítico, nos encontramos aquí con "el mantenimiento de una situación convenida ${ }^{2}$ entre dos partenaires" (P67:267), no se puede descuidar ese "constituyente ternario que es el significante introducido en el discurso que en él se instaura, el que tiene nombre: el sujeto supuesto saber" (P67: 267, mi énfasis). El teatrista -particularmente cuando oficia de director del proyecto- no se involucra como persona, sino que asume la posición de sujeto supuesto saber en dicha situación; saber supuesto, por lo demás, del que él no sabe nada (P67: 267). La consecuencia es relevante: el psicoanálisis es una praxis y como tal tiene un nivel teórico, pero no opera por una dialéctica entre teoría por un lado y práctica por el otro, que supondría un encuadre científico basado en la aplicabilidad, la demostración y la justificación a nivel metodológico. No es por aplicación de la teoría que se aborda la clínica, porque el analista, frente a un caso, debe colocarse en la posición de no-saber. Porque se trata de una praxis, "la tarea no consiste tanto en comparar sistemas de ideas en cuanto ideas, sino explorar sus dimensiones performativas" (Laclau, 2014: 28). Precisamente porque el psicoanálisis es una praxis que explora lo performativo en muchos niveles
1. La cuestión tan debatida en el psicoanálisis de acto analítico, me llevó a repensarlo desde la praxis teatral como acto performativo. Este desarrollo se podrá leer en un trabajo inmediatamente previo a este ensayo y muy ligado a él, de próxima publicación bajo el título "Pedagogía y deseo: La creatividad teatral en español en la universidad estadounidense". 2. En el Seminario 11 Lacan define la praxis: “¿Qué es una praxis? [...] Es el término más amplio para designar una acción concertada por el hombre, sea cual fuere, que le da la posibilidad de tratar lo real mediante lo simbólico. Que se tope con algo más o algo menos de imaginario no tiene aquí más que un valor secundario" (14). Importa enfatizar el uso del término "concertada"; en la P67 usa "convenida", porque el carácter contractual es fundamento del lazo que permitirá la realización de esa praxis. Para un comentario sobre este punto crucial de la praxis teatral, ver mi "Pedagogía y deseo". 
(incluida, por supuesto, la transferencia [véase Abad, 2016]), es la más cercana a nuestros propósitos en el trabajo teatral. La praxis teatral, como el psicoanálisis, avanza y retrocede caso por caso, porque frente a un montaje hay que recordar "la insistencia de Freud en recomendarnos abordar cada caso nuevo como si no hubiéramos adquirido nada de sus primeros desciframientos" (P67:267). Y, como subraya Lacan en la misma Proposición, esto "no autoriza en modo alguno al psicoanalista a contentarse con saber que no sabe nada, porque lo que está en juego es lo que él tiene que saber", a saber, cómo opera la lógica del significante y de los discursos, ${ }^{3}$ esto es, cómo "se articulan en cadena de letras tan rigurosas que, a condición de no faltar ninguna, lo no sabido se ordena como el marco del saber" (P67:268).

El proceso de montaje teatral debería llevar, como en análisis, a esa destitución subjetiva en la que, vía el trabajo analítico con la trasferencia, adviene ese resto -el espectáculo-, ese objeto a causa del deseo, "como un determinante de su división [que] lo hace caer de su fantasma y lo destituye como sujeto" (P67:270). Jacques-Alain Miller, considerando el final del análisis, tal como el espectáculo es para el teatrista el final de su proceso creativo, señala que tuvo en Lacan dos momentos: el primero, ligado a la metáfora paterna, cuando el analizando alcanzaba la "desidentificación fálica" (2017:46); el segundo, más avanzada su enseñanza, se planteó con "la caída del objeto a" (47). Ambas van a operar en la praxis teatral aunque, como en el psicoanálisis, también la segunda tendrá prevalencia. Ambas operan con mecanismos distintos y tienen consecuencias también diferentes, particularmente respecto de la autoridad. En efecto, en la desidentificación fálica, no obstante, el sujeto instituye un Otro; en la caída del objeto $a$, en cambio, hay "una perspectiva destituyente del sujeto y además del sujeto supuesto saber" (Miller, 2017: 47-48), esto es, el Otro se presenta como barrado, con una falta, no es garantía de nada, es apenas la "ilusión necesaria del sujeto supuesto saber que se desvanece al final del análisis y revela hasta qué punto no es esencial (Miller, 2017: 47); precisamente, muestra a la autoridad "desvanecida bajo los aspectos del sujeto supuesto saber" (Miller, 2017: 47). El teatrista, entonces, tal como ocurre para el analista, se autoriza a partir de allí por sí mismo.

Siguiendo esta perspectiva psicoanalítica, podemos decir que el teatrista, cuando está en función de la dirección del espectáculo o el proyecto de puesta en escena y precisamente porque dirige el proceso, interviene en él "menos por lo que dice y hace que por lo que es" (LD: 561). Y lo que es, se define por su posición, la de sujeto supuesto saber que, al final, será un semblante que cae, dejando al grupo, sus actores, frente al objeto a de su deseo. En este sentido, su función se focaliza en el manejo de la transferencia, porque es en ella donde se produce "el desdoblamiento que sufre allí mi persona" (LD: 562). Al hacer el muerto, su silencio resulta productivo para revertirle al actor las fantasías que éste deja emerger durante las improvisaciones. Si se puede hablar aquí de una "política"-vocablo usado por Lacan-, ésta consiste en que el director "haría mejor en situarse por su carencia de ser que por su ser" (LD: 563). ${ }^{4}$ Se resguarda así de imponer su idea de la realidad, si entiende que no son los actores los que resisten, sino él; en todo caso, éstos se defienden del deseo del director.

Lo mismo ocurre con el actor: si hay en él resistencia, es porque se opone a la sugestión impuesta por el director: y esa resistencia "cuando se opone a la sugestión, no es sino deseo de mantener su deseo" (LD: 605). Por su parte, "el analista es aquel que resiste la demanda, no como suele decirse para frustrar al sujeto, sino para que reaparezcan los significantes en que su frustración está retenida" (LD: 589). Y esa frustración tiene que ver con demandas antiguas, con insatisfacciones no de las necesidades, sino de la demanda misma, como demanda de presencia del Otro, como demanda de amor, del don. Es allí donde podemos constatar que el deseo "es lo que se manifiesta en el intervalo que cava la demanda más acá de ella misma, en la medida en que el sujeto, al articular la cadena significante, trae a la luz la carencia de ser con el llamado a
3. Referencia a los famosos cuatro discursos (del Amo, de la Universidad, de la Histeria, del Analista), que fundan tipos de lazo social. Se agrega luego el mal denominado "discurso capitalista”, aunque no es propiamente un discurso en la medida en que no funda un lazo sino, más bien, lo impide. Para una discusión de estos discursos en la praxis teatral, ver mi ensayo "Los cuatro discursos lacanianos y las dramaturgias”(2011)

4. Como veremos más adelante, esta perspectiva tomará múltiples consecuencias en cuanto a los liderazgos al momento de los activismos políticos, como diferenciadas de las verticalidades partidistas y de los encuadres fascistas del pasado. 
recibir el complemento del Otro, si el Otro, lugar de la palabra -"el otro escenario" [LD: 598] -es también el lugar de esa carencia" (LD: 597). El Otro no puede colmar la falta del sujeto, esto es, su deseo, porque no tiene con qué hacerlo, "puesto que a él también le falta el ser" (LD: 597).

Vana y peligrosa resulta, entonces, la estrategia de un director que se proponga-como lamentablemente es la norma - frente a su elenco en posición de tenerlo todo, de ser completo, el saber incluido, para dárselo a sus actores. No lograría otra cosa que muñecos gesticulando por imitación su propia veleidad, réplicas de sí mismo, situación que, no hace falta insistir, va más allá de toda ética analítica, en la que el analista no puede posicionarse como sabiendo algo respecto al bien y al mal, al supuesto bien del y para el sujeto (sus actores, el público), las ya mencionadas buenas intenciones de la moral kantiana. Cuando esto ocurre, estamos indudablemente frente a un dispositivo autoritario, incluso cuando la comedia se matiza con afectos paternales; en esta situación el director, por mediación del lenguaje, "sostiene en cuanto sujeto" a su semejante, sin percibir hasta qué punto está considerándose a sí mismo "como el tramoyista, o incluso como el director de escena de toda la captura imaginaria de la cual por lo demás él no sería más que un títere vivo" (LD: 606, cita modificada) 5 . A pesar de su buena voluntad e intenciones, no deja de ejercer ese "principio maligno" que es el poder, "el poder de hacer el bien, ningún poder tiene otro fin, y por eso el poder no tiene fin" (LD: 609), pero al intentarlo, el director iría mal encaminado, porque, en primer lugar, nadie puede saber cuál es el bien para otro sujeto y, en segundo lugar, porque la cuestión del arte no es el poder sino la verdad, la verdad del deseo, es decir, en la dimensión del inconsciente. Ya lo había planteado Walter Benjamin cuando, en su "Truth and Truths", afirmaba que "Works of art are the proper site of truths" (1996: 278), lo cual a su vez nos manifiesta por qué, desde sus inicios, el psicoanálisis no dudó en atravesar la puerta regia del teatro (Edipo Rey), la literatura y el arte en general. Y este atravesamiento, poco tiene que ver con ese adjetivo tan insidioso y erróneo que se le ha adjuntado al psicoanálisis, cuando se habla de un psicoanálisis aplicado, siendo que es de esa inmersión en la arte como residencia de la verdad la que funda su conceptualización y no a la inversa.

\section{Acto: izquierda lacaniana y política lacaniana}

Ya hemos esbozado la relación del director con sus actores. Corresponde ahora interrogarnos sobre cuál es, pues, desde esta perspectiva de la praxis teatral y el psicoanálisis, la posición del teatrista respecto al público, a ese Otro para el cual trabaja. ¿Deberá mantener esta posición de esclavo que trabaja para el goce del Otro, o bien hacer trabajar al Amo? ¿Ambas? Así como Lacan planteó que el analizante no resiste, que el que resiste es el analista ("no hay otra resistencia al análisis sino la del analista mismo" [LD: 568]), nosotros podríamos llevar la cuestión a la dimensión en la que el teatro toma sentido: se monta un espectáculo, se trabaja para un público. ${ }^{6}$ Parafrasenado a Lacan, podríamos decir entonces, negando algunas afirmaciones de la filosofía del teatro, que el público no especta; el único que especta es el teatrista. El público, en su heterogeneidad, proviene de diversos sectores sociales, con problemáticas diversas; lo que los convoca no es una celebración comunitaria frente a un escenario en el que contemplaría la producción de poíesis realizada por los artistas; los trae al teatro una serie de demandas insatisfechas que pueden o no entrar en relaciones equivalenciales (Laclau) para promover un acto también performativo. Y para eso la mayor parte de las veces paga -como el analizante- la admisión, amén de los otros gastos que supone el acercarse al lugar de la representación. ${ }^{7}$

En los años recientes ha comenzado a diseñarse una extensión, para algunos indebida, del psicoanálisis hacia el campo de lo social, en la medida, fundamentalmente, en
5. La versión española traduce "autrement" como "en caso contrario", lo cual crea confusión sobre el párrafo: "Qu'il soutient en tant que sujet ", veut dire que le langage lui permet de se considérer comme le machiniste, voire le metteur en scène de toute la capture imaginaire dont il ne serait autrement que la marionnette vivante" (29).

6. En otros trabajos hemos distinguido conceptualmente, en el marco de la praxis teatral, la diferencia entre espectador y público. El espectador es una máscara espectatorial construida por el teatrista durante el montaje. Ver mis ensayos “El director y su público: la puesta en escena y las estructuras espectatoriales" (2012); "Praxis teatral y puesta en escena: la psicosis como máscara espectatorial en el ensayo teatral (1- ${ }^{-}$2013] y $2^{-}$[2017] partes)".

7. En los rituales y ceremonias se paga también, pero con la culpa sacrificial. Este aspecto convivial lo dejaremos para comentar en otra oportunidad. 
que debe responder a los nuevos síntomas que aparecen en la sociedad capitalista, globalizada y neoliberal. A esta aproximación a lo social, se la ha denominado "izquierda lacaniana" y supone un trabajo minucioso a partir de conceptos psicoanalíticos, mayormente en su versión lacaniana, para trabajar la cuestión de la emancipación del sujeto de la alienación a la que lo somete la sociedad consumista contemporánea. Pensadores de la talla de Ernesto Laclau, Slavoz ŽiŽek, Jean Copjec, Judith Butler, Jorge Alemán, Nora Merlin, entre otros, han comenzado a pensar las formas en que ancla la alienación subjetiva en la actualidad, más allá de la ya trabajada conceptualmente por Marx en El Capital como relativa a la mercancía. Se trata de nuevos horizontes de pensamiento que intentan desafiar las celebraciones sobre el fin de la historia y de las ideologías, del capitalismo como culminación insuperable de la Historia; en sus diferencias, estos trabajos de izquierda lacaniana, no obstante, se esfuerzan para dar una alternativa al duelo y la melancolía en estos tiempos crepusculares, ${ }^{8}$ una vez comprobada la caída de la función paterna, de la ley y la autoridad, y de las derrotas de la izquierda política en todas sus variantes. A pesar del matiz emancipador que tienen algunas propuestas sociales, lo que está en juego es el sujeto mismo, en la medida en que dichas propuestas no dejan de imponer subjetividades pre-formadas a las que el sujeto debería subsumir su ser a costa de perder su propia singularidad. Y esto lo había previsto ya Sartre cuando, en El sery la nada, a propósito del mesero homosexual, expresa que el Otro "[1]e exige, pues ser lo que es para no ser más lo que es" (111). Al asumir la identidad gay, tal como la ha fijado el movimiento y se la apropiado el mercado de consumo, se elimina la singularidad de la homosexualidad del mesero, no necesariamente contemplada por la subjetividad institucionalizada. Esa singularidad constituye precisamente lo inapropiable por el capitalismo neoliberal, como veremos más adelante.

Ahora bien, una izquierda lacaniana tiene, si se quiere, como marco más general, una política lacaniana. Y ésta es también importante para la praxis teatral, porque se instala en el acto analítico, que para nosotros teatristas bien podría denominarse acto performativo. El acto analítico es el que "abre a la metonimia de la cadena significante, desestabiliza el narcisismo del Plateo un acto" (Miller 97); se resguarda fundamentalmente la cadena metonímica por la que se desplaza el deseo y, precisamente por ese desplazamiento, el narcisismo pierde los apoyos que le darían, como quien dice, la imaginaria solidez y prepotencia de un "hice este espectáculo". Más que de un acto, como lo dice Jacques-Alain Miller recordando a Sartre, se trata de un gesto. Lo importante respecto al acto analítico es que se abre al futuro, se mide por sus consecuencias. "Juzgar el acto por sus consecuencias, que el estatuto del acto depende de sus consecuencias, es para mí un principio de la política lacaniana" (Miller 97). En ese sentido, Miller subraya que se trata de "un principio hegeliano" y no kantiano. En efecto, desde la perspectiva kantiana habría una intención recta, una buena voluntad que orientaría al acto desde antes de su realización y, como ocurre generalmente cuando se quiere legislar sobre el bien para un sujeto, se termina en catástrofes, en particular al capturarlo, vía sugestión, imitación e identificación, por los Ideales del yo, sean los de la cultura, los del analista o del teatrista. Al plantear el acto analítico a partir de las consecuencias, se retoman las críticas hegelianas a la visión moral kantiana. Y como de buenas intenciones está lleno el infierno, el psicoanálisis sabe que hay una intencionalidad inconsciente que solo puede ser recuperada, si puede decirse así, retroactivamente según los derroteros de la metonimia de la cadena significante. Volveremos a esto cuando recordemos la frase de Picasso que a Lacan tanto le gustaba citar: "Yo no busco, encuentro". No hay, pues, una idea, una intención, una voluntad previa a la obra, basada en el conocimiento del artista; hay un encuentro con lo real desde el cual hay que actuar, actuar desde el no-saber, y cuyas consecuencias se verán a posteriori. Retomando a Benjamin, " $[k]$ nowledge and truth are neveridentical; there is no true knowledge and no known truth. Nevertheless, certain pieces of knowledge are indispensable for an account of the truth" (1996: 279); lo que nos recuerda
8. Para un desarrollo mayor de este tema ver mi ensayo "El bifurcado camino de la melancolía: la civilización del espectáculo y el futuro del teatro latinoamericano" (2017) 
aquello de Lacan de que la verdad se instala por el significante en su mediodecir. Si hay metonimia, hay deseo, con lo cual hay Otro. El acto performativo del teatrista -como el acto analítico del analista-tiene efectos, consecuencias en ese Otro; toma "en cuenta la reacción del Otro, lo que dice y lo que va a hacer" (Miller, 2017: 98). Es decir, el teatrista especta.

\section{Teatro, público, demanda}

Ernesto Laclau, en su libro La razón populista, va a intentar dar una definición positiva del populismo, como instancia espontánea y temporaria en la que se articulan sectores diversos de la sociedad a partir de poner en relación equivalencial sus demandas insatisfechas, incluso a costa de renunciar a ciertas particularidades. Su tesis consiste en probar que "el populismo es la vía real para comprender algo relativo a la constitución ontológica de lo político como tal" (2014: 91). Su libro comienza con algo que nos importa a quienes estamos en la praxis teatral: la diferencia entre masa y pueblo, que viene debatiéndose en la sociología desde Le Bon hasta Freud, y después. Como sabemos, la masa es concebida como un grupo de individuos que, por medio de la sugestión, la imitación y la identificación a un líder, puede alcanzar altos grados de violencia y constituirse como una amenaza a los regímenes democráticos. Freud va a enfocarse particularmente en este tema en su Psicología de masas y análisis del yo, publicado en 1921, cuando ya percibía la inminencia de una amenaza totalitaria nazifascista que, todavía, carecía de esa designación. Laclau, por lo tanto, trata de rescatar el término populismo dándole un sentido positivo, casi de la misma manera a como la teoría queer tomó ese vocablo peyorativo para autodesignarse, mediante un trabajo de resemantización del término.

No sería éste el lugar de puntualizar detalladamente el libro de Laclau. Baste decir que subraya la peligrosidad de abordar los movimientos radicales de protesta y demandas sociales a partir de mecanismos basados en la sugestión, la imitación y la identificación, con los que se había caracterizado al populismo. Sin duda, cada uno de esos términos tiene que ser leído en el campo político, aunque obviamente procede, en forma ya bastante elaborada, del ensayo freudiano. La cuestión política de la propuesta de Laclau, para decirlo rápidamente y a costa de cierta injusticia, apunta a la necesidad de ofrecer una conceptualización optimista a las diversas demandas sostenidas por grupos también diversos en la sociedad actual, una vez asumido el hecho de que, a pesar de Marx, la revolución y el cambio no vendrán por un desarrollo inmanente al capitalismo por medio de la lucha de clases o por acción del proletariado.

Al comienzo mismo de su libro, Laclau establece las demandas como la unidad del grupo (2014:9). Los grupos feministas, en toda la variedad de sus reclamos, los grupos LGBTQ, los sectores que reclaman derechos humanos diversos y justicia por los genocidios, los grupos ecologistas, los pobres, etc., surgen a partir de insatisfacciones desemejantes que, de no conseguir cierto tipo de convergencia, quedan incapacitados para enfrentar al Estado u otras instituciones, esto es, a los que deberían satisfacer las demandas particulares de cada sector. Frente a esto, Laclau realiza un exhaustivo trabajo conceptual para investigar cómo esas demandas particulares, que denomina democráticas, y que son particulares y diferenciales, en ciertos momentos admiten articularse en una cadena de relaciones equivalenciales a fin de potenciar su poder político para efectuar el reclamo. ${ }^{9}$

En lo que a la praxis teatral respecta, por el momento nos interesa enfatizar la cuestión de la demanda, que Laclau toma como unidad mínima conceptual para construir su proyecto. ${ }^{10}$ En un momento determinado múltiples demandas procedentes de grupos con insatisfacciones diversas se ponen en equivalencia, es decir, admiten la
9. Las recientes marchas para reclamar la legalización del aborto en Argentina, con sus pañuelos verdes que se internacionalizaron, son un ejemplo concreto de un momento populista, en la medida en que los integrantes de esas movilizaciones provienen de sectores sociales diversos (clase, edad, raza, nivel educativo, sexo), carecen de líderes nominados, renuncian a sus particularidades sectoriales y aúnan su demanda con el significante del pañuelo verde, significante vacío, que pone a dichas demandas en una relación equivalencial, dejando por el momento de lado otros reclamos ya más puntuales de cada grupo (desempleo, marginación, falta de acceso a la educación, desamparos jurídicos, salarios diferencias para las mujeres, etc.). Se trata de un momento contingente, un acto instituyente que no puede predecirse "científicamente", como no puede predecirse un sueño o un lapsus. 
posibilidad de que "una diferencia, sin dejar de ser particular, asuma la representación de una totalidad inconmensurable" (2014:95). Es decir, una de las particularidades de ese grupo de demandas diversas asume la representación, si se quiere, la universalidad para dar lugar a la construcción de hegemonía, esto es, la instalación de una frontera que discierne el antagonismo entre quienes demandan y aquellos que deberían responder a esas demandas. Ahora bien, esa representación 'universal' de la particularidad de la demanda, esa "identidad hegemónica pasa a ser algo del orden del significante vacío" (Laclau, 2014: 95). Es un significante vacío porque representa múltiples demandas sin conservar la relación significante/significado avalada por el diccionario o por la cultura. Ese significante, esa demanda convertida en significante, es una pura negatividad (Laclau, 2014: 125); lo único que las une es ese significante vacío que 'representa' no la particularidad específica de cada demanda, sino "el hecho de que todas ellas [las demandas] permanecen insatisfechas" (Laclau, 2014: 125). ${ }^{11}$ Cuando hay fronteras equivalenciales alternativas, es decir, proyectos hegemónicos rivales, ${ }^{12}$ cada uno con su significante, entonces Laclau lo califica de 'significante flotante":

Como podemos ver, las categorías de significantes "vacíos" y "flotantes" son estructuralmente diferentes. La primera tiene que ver con la construcción de una identidad popular una vez que la presencia de una frontera estable se da por sentado; la segunda intenta aprehender conceptualmente la lógica de los desplazamientos de esa frontera. En la práctica, sin embargo, la distancia entre ambas no es tan grande. (167)

Resulta importante -y lo será para nuestra praxis teatral-retener la importancia de la heterogeneidad de las demandas como instancia indispensable para el populismo; Laclau asimila esta heterogeneidad a lo real lacaniano (139), es decir, aquello doloroso, ese exceso de goce que no tiene significante que lo represente y que, como veremos, también lo remite a ese horizonte en que la demanda apunta a una satisfacción mítica, plena y total.

Estamos, como puede verse, en un momento de la lucha por los reclamos en la que, espontáneamente -si podemos decirlo así- los diversos sectores insatisfechos se organizan a partir de un significante vacío que los representa a todos, aunque se trate de una de las particularidades, quedando las demás momentáneamente subsumidas en ese significante. Laclau propone denominar 'pueblo' y 'populismo" a este momento en que emerge "una articulación equivalencial de demandas" (2014: 99). No es una movilización programada por un líder y dinamizada por la sugestión y la identificación, sino que es un momento -contingente, imprevisible, inapropiable - en que los sectores insatisfechos asumen un rol de sujeto, de agente en la construcción de hegemonía para luchar por sus reclamos. Obviamente, esta cuestión se complica cuando pasamos a trabajar a partir de un ejemplo concreto de contexto. Aunque "la equivalencia no intenta eliminar las diferencias" (Laclau, 2014: 105), aunque este significante vacío se instala operativamente como "totalización populista" (Laclau, 2014: 107), lo común es que, una vez pasado ese momento instituyente (como lo denomina Jorge Alemán[2016]), adviene lo instituido en el que las particularidades no tenidas en cuenta antes exigen su representación, reiniciando el proceso: "la emancipación siempre recomienza" (Alemán, 2016: 138), para lo cual hay que apresurarse a desidentificarse, no intentar repetir, retomar lo realizado desde una nueva perspectiva. Lo mismo ocurre para el teatrista: cada montaje -incluso con el mismo elenco-es un recomenzar para el que no ayuda demasiado la repetición de lo ya realizado, salvo si se lo considera desde una nueva perspectiva.

Ahora bien, la positividad de ese significante vacío se aprecia en cuanto permite articular una subjetividad popular frente al enemigo, construido y definido en cada
11. En un momento este significante puede ser el nombre de una individualidad, el nombre de un líder (Laclau, 2014: 130), pero no es él quien precede a la relación equivalencial. 12. Un ejemplo de proyectos hegemónicos rivales también procede de Argentina, pero se ha dado igualmente en Brasil y Ecuador, respecto a las investigaciones y demanda de juicios por corrupción a los gobiernos de Cristina Fernández de Kirchner, Lula da Silva y Rafael Correa. 
caso histórico particular-diferencia clave con el proletariado de Marx. Si al institucionalizarse la demanda se disuelve la frontera política establecida en el antagonismo, ${ }^{13}$ "si esta última desaparece, el 'pueblo' como actor histórico se desintegra" (Laclau, 2014: 117). Veamos cómo el mismo Laclau sintetiza su propuesta:

Todo nuestro enfoque sobre el populismo, como hemos visto, gira en torno a las siguientes tesis: (1) el surgimiento del pueblo requiere del pasaje -vía equivalencias- de demandas aisladas, heterogéneas, a una demanda 'global' que implica la formación de fronteras políticas y la construcción discursiva del poder como fuerza antagónica; (2) sin embargo, como este paisaje no se sigue de un mero análisis de las demandas heterogéneas como tales -no hay una transición lógica, dialéctica o semiótica de un nivel a otro- debe intervenir algo cualitativamente nuevo. [...] Este momento cualitativamente diferenciado es lo que hemos denominado "investidura radical”. (2014: 142, mi énfasis)

Podemos trasladar esta cita al campo de la praxis teatral: un grupo de teatristas se reúne para montar un espectáculo. Tienen necesidades no satisfechas: laborales, artísticas, políticas. Vienen de sectores diversos, con formaciones y experiencias teatrales variadas. Cada uno tiene expectativas diferentes respecto a lo que se quiere hacer. Alguien tiene que asumir la dirección de proceso en algún momento y eso requiere consenso, salvo que ya se haya resuelto de antemano desde la producción o bien desde el prestigio de alguno de esos teatristas. Hay, pues, una heterogeneidad de demandas aisladas que es necesario poner en relación equivalencial para que el proyecto pueda ponerse a funcionar y llevarse a cabo. Sin embargo, esa demanda que asume la equivalencia instala antagonismos, la formación de una frontera entre quien dirige y quien produce, entre quien dirige y los actores, entre quien dirige o el grupo y los técnicos, etc. La riqueza del proceso emerge justamente de estos antagonismos y la forma en que van construyendo hegemonía. El director, los actores, el productor o alguna agencia externa de pronto logran dirimir el significante vacío que permite un acto performativo instituyente y permite o fertiliza la dinámica artístico-política del proyecto. No obstante, como plantea Laclau, aparece un elemento "cualitativamente nuevo".

Ese aspecto cualitativamente nuevo es el afecto, "es decir, el goce" (Laclau, 2014: 148). Vamos a volver a esta cuestión de la "investidura radical", de raigambre freudiana. Por ahora, baste decir que ese significante vacío representa la cadena equivalencial en la medida en que está investido (sobreinvestido) de afecto. Observemos de paso cómo Laclau trae a la teoría política esta cuestión del afecto/goce, que había quedado de lado en las aproximaciones racionalistas; cómo incorpora el goce como una contingencia y no derivado de una lógica-dialéctica o no-según postulan los marxistas. La cuestión del afecto en tanto goce ${ }^{14}$ ha sido siempre un punto de malestar en el campo teatral: El valor de esa contingencia, su conceptualización, ha sido un punto crucial en los debates psicoanalíticos actuales: Lacan trabaja esta categoría de la contingencia en varios sentidos. Podemos retener para nuestra praxis teatral, la necesidad de salirse de los determinantes de la coherencia ${ }^{15}$ y de la determinación simbólica (Laclau también discutirá por ello la validez actual de la categoría marxista de "determinación en última instancia de la economía"). Se positiviza, en cambio, la cuestión del azar, el encuentro azaroso con lo real, con el goce, esto es, a nivel del cuerpo, que, ya en el Seminario 24 -después de su trabajo con James Joyce en el Seminario 23-Lacan llega a revalorizar el carácter imaginario de ese significante que hay que inventarle a lo real, y que ya no se instala como 'verbal', sino precisamente como imagen. Las consecuencias de esta invención no se hacen esperar en relación a la creatividad que podría propiciar la praxis teatral.

A partir de trabajos de Jean Copjec, Laclau no puede dejar de lado la cuestión pulsional que involucra el cuerpo y la aspiración mítica (en el sentido de que habría
13. Toda nuestra praxis teatral se construye sobre la dimensión agonística, desde nuestro concepto de teatralidad, hasta nuestra conceptualización de la "frontera" en Dramaturgia de frontera/dramaturgias del crimen. Para usar aquí las palabras de Laclau, más que una definición geopolítica de frontera, resulta mejor conceptualizarla desde el psicoanálisis como esa instancia narcisista en que "el otro excluido es la condición de mi propia identidad, la persistencia de esta última requiere también la presencia de un otro antagónico" (2014: 176-177). Para un desarrollo más extenso, ver nuestro libro ya mencionado, en el que, como Laclau, nos alejamos de una definición esencialista de la identidad, incluso favoreciendo en nuestro análisis la cuestión de las identificaciones, porque ponen en juego las categorías lacanianas de alienación y separación respecto de los mandatos sociales, del Ideal del yo, algo que Laclau solo trabaja lateralmente en La razón populista.

14. Hay que hacer aquí una aclaración para trabajar en el futuro: para Lacan, la angustia es un afecto; la angustia no engaña porque no es sin objeto. Digamos que hay allí un objeto que angustia al sujeto y promueve sus inhibiciones, resistencias y defensas. Muchas técnicas actorales han enfrentado este problema. En cuanto al goce, aunque Laclau lo plantea como un afecto, hay que tratarlo más extensivamente, porque está ligado a lo real, a la pulsión de muerte, a la repetición. Hay un núcleo de goce en el síntoma, que muchas veces es la zona de confort, la zona conocida del sujeto a pesar de su queja y el malestar que le provoca, razón por la cual no quiere renunciar a dicho goce para enfrentar lo desconocido. Hay también un sentido gozado del fantasma que habría que atravesar, enfrentando vicisitudes diversas. Hay, finalmente, un sinthome, un modo de goce incurable del sujeto con el que tiene que saber-arreglárselas. Si el síntoma puede 'levantarse' por medio de la interpretación para abrir la cadena metonímica del deseo bloqueada por él, el sinthome no es removible. Todas estas cuestiones aparecen durante cualquier ensayo teatral y nos queda la tarea de revisar los aportes de maestros como Stanislavski, Grotowski, Barba, etc. desde estas cuestiones psicoanalíticas.

15. Podemos leer esto desde las imposiciones aristotélicas a la dramaturgia, por ejemplo, o la 'naturalización' de la política de la mirada en la teatralidad del teatro, con o sin el edificio de la sala a la italiana. Para un desarrollo más detallado ver mi ensayo "Una posible genealogía de lo político teatral: El régimen de verdad de la escena teatral"(2017) 
ocurrido en la relación madre/hijo y que, en términos políticos, Laclau asimila a esa demanda mítica de "la sociedad completamente reconciliada" [152]) de las demandas en su aspiración a una satisfacción plena y completa, original, que obviamente resulta siempre insatisfecha. Define así lo que entiende por 'investidura radical:: "el hacer de un objeto la encarnación de una plenitud mítica" (2014: 148). Habría un objeto parcial, objeto de deseo, objeto $a$ en la perspectiva lacaniana que, a pesar de su parcialidad, "asume la representación de una totalidad mítica" (Laclau 149). Por eso Laclau califica de 'idénticas' la lógica del objeto a y la lógica hegemónica (148-149).

\section{Estudios teatrales vs. praxis teatral: masa vs. pueblo}

Resulta indispensable establecer aquí una diferenciación en las perspectivas de la filosofía del teatro, tal como la ha planteado Jorge Dubatti, y la de la praxis teatral. La filosofía del teatro o los estudios teatrales se orientan por el camino de la ciencia y la producción del conocimiento, lo cual es válido porque el intento apunta a dar una base conceptual a los estudios teatrales, tal como se ejercen en la academia. Mucho más difícil, desde el punto de vista de la academia, es alojar a la praxis teatral. ${ }^{16}$ Dubatti nos plantea que

en la teatrología argentina y mundial hoy están en plena vigencia, con mayor o menor desarrollo, las construcciones científicas de la semiótica (teatral y/o literaria), la lingüística, la poética, la antropología teatral, la sociología teatral, la etnoescenología, el psicoanálisis aplicado al teatro, la hermenéutica, la filosofía del teatro, los estudios económicos aplicados al teatro, entre otras.

Cada una de estas disciplinas realiza construcciones científicas diversas del teatro. (2011: 27, mi énfasis)

Ya hemos hecho mención a la improcedencia de hablar de un psicoanálisis aplicado. También es debatible que el psicoanálisis, al menos hoy, pueda sostenerse desde una perspectiva científica. Sin duda, constituyó el anhelo de Freud y del primer Lacan; sin embargo, a lo largo de su enseñanza, Lacan fue cuestionando la ciencia y el sujeto de la ciencia hasta el punto de arribar a la conclusión de que el psicoanálisis ni era ciencia ni religión; en todo caso, debería estar alineado con el arte; el psicoanálisis, después de todo, como el arte mismo -como nos recordaba Benjamin-, es una praxis, donde lo que prima es la cuestión de la verdad, del saber-hacer con sus avatares técnicos y conceptuales. Al enfocarse en la singularidad del sujeto, al trabajar en el caso por caso, la batería conceptual del psicoanálisis, aun en su abstracción, no habilita ningún tipo de generalización ni universalización típica del conocimiento; al orientarse hacia el saber inconsciente, está siempre confrontada a cada caso, se va transformando (Freud hizo cambios a su teoría varias veces a partir del fracaso de varios de sus casos). El psicoanálisis es una disciplina que, como el arte, opera solo en lo que Gastón Bachelard (2000) - quien, esperanzado en un "psicoanálisis del conocimiento objetivo"- denominaba "contexto de descubrimiento" y, a diferencia de la psicología, que sí es ciencia y trabaja sobre el sujeto cartesiano, carece de un contexto de demostración y justificación. Bachelard captó, a su manera, las travesuras del inconsciente en su famoso concepto de "obstáculo epistemológico". Lo cierto resulta en que es imposible hacer encuestas, por ejemplo, desde la perspectiva psicoanalítica. Lacan gustaba citar la famosa frase atribuida a Picasso: "Yo no busco, encuentro". De modo que el psicoanálisis ni siquiera opera por formulación de hipótesis; solo se atiene al encuentro con lo real, siempre inesperado, sorpresivo; al hallazgo, siempre fallido, del objeto del deseo. Otra razón para descalificar el adjetivo 'aplicado' atribuido al psicoanálisis.
16. Abordamos en tema de la enseñanza de la praxis teatral, tan problemática como la enseñanza del psicoanálisis y su turbulenta historia respecto de la Escuela y las instituciones, en ese ensayo de próxima aparición: “Pedagogía y deseo: la creatividad teatral en español en la universidad estadounidense". También se puede leer mi libro Praxis teatral. Saberes y enseñanza. Reflexiones a partir del teatro argentino reciente.(ob. cit.) 
La praxis teatral, por el contrario, al instalarse a nivel de la creatividad y trabajar a partir del acto no se lleva bien con los estudios teatrales. En la medida en que el acto performativo -como el analítico-se juzga por sus consecuencias, como se desconoce retroactivamente que haya sido realmente un acto, hace cortocircuito con las demandas pedagógicas institucionales, académicas. Un acto no es un planificable en su origen, no está del lado de las intenciones conscientes; surge de una contingencia y puede resultar fallido, circunstancia que la mayoría de las veces lo torna logrado justamente por ser fallido; por eso se lo juzga por la ética de las consecuencias. "Es necesario-escribe Miller-esperar para saber si lo fue" (96). Parte de un no-saber, del sinsentido de lo real, suspende todo conocimiento y apunta al deseo: "La política lacaniana es una cierta política de la insistencia, la insistencia de hacer salir el deseo oculto tras las buenas razones y la buena intención" (Miller, 2017: 104), razón por la cual a veces hay que confrontar lo políticamente incorrecto. Solo si al final del proceso de trabajo abre la cadena metonímica del deseo, podemos considerarlo un acto: "juzgar el acto por sus consecuencias es abrirlo al futuro" (Miller, 2017: 96). Apuntando al deseo (que "es siempre asunto de horizonte" [Miller, 2017: 106]), la praxis teatral solo puede orientarse por la praxis psicoanalítica, no interesada en el conocimiento como un universal generalizable, sino en la contingencia y el saber relativo a la singularidad de un sujeto, esto es, lo no universalizable ni generalizable, y esto es lo que hace inmanejable, indisciplinable, incontrolable la praxis teatral para la academia. El acto es siempre un recomienzo desde cero, no tiene rutina, no tiene memoria (Miller, 2017: 72). La academia tiene demandas a las que la praxis teatral no (siempre) puede responder. Esta cuestión no es ajena a los avatares de la institucionalización del psicoanálisis. Miller hace referencia a "nuestra imposibilidad del acto en la Escuela" (2017: 79) y entonces muestra los dos lados de la incompatibilidad: "Hay Escuela y hay psicoanálisis" (2017:74, énfasis de Miller). Hasta cierto modo, la escuela o la academia, orientada a brindar y garantizar ciertos protocolos de profesionalización, hacen olvidar el acto, no le ofrece un lugar institucional; a cambio, deja espacio para la experiencia, marcada por la rutina opuesta a lo vivo del acto. "El acto analítico, -plantea Miller- lo que tiene de decisivo, de vivo, se olvida en la rutina de la experiencia" (2017: 71). Así, mientras la academia inviste con certificaciones de grado o post-grado al estudiante de teatro, no puede sin embargo extender esa certificación a la praxis teatral basada en el acto, difícil de evaluar artísticamente. El diploma autoriza profesionalmente al estudiante; en cambio la praxis teatral basada en el acto performativo, si se quiere el riesgo del acto, su contingencia, solo puede llevar al teatrista a autorizarse a sí mismo. El teatrista deviene un solitario, que no cede en su deseo y cuya praxis no tiene garantías en ningún un Otro institucional porque la institución está, precisamente por ser institución, incapacitada de alojar lo instituyente propio del acto performativo. Como vemos, Lacan y los analistas tuvieron y tienen que enfrentar muchos problemas en relación a la enseñanza y la validación del analista, al punto que el mismo Lacan terminó cerrando su propia Escuela.

¿Cómo regular y a partir de qué parámetros la consistencia artística de un acto performativo? La academia impone validarlo a través del conocimiento, pero la praxis teatral opera sobre lo inconsciente y el saber inconsciente, sobre el deseo, para el cual, como vimos, no hay ciencia posible debido a su singularidad radical. Los estudiantes de teatro se ven, entonces, en la encrucijada de tener que dar cuenta de un proceso por medio de bibliografías diversas, pero prestigiadas por el discurso de la Universidad que, en la mayoría de los casos, ni estuvieron desde el inicio del acto performativo ni pueden dar cuenta de él. Hay un "sentimiento de fracaso [que] se capta cada vez que se percibe que el respeto de las formas triunfa sobre el real en juego" (Miller, 2017:36). Se establece así un doble conflicto entre praxis teatral y academia, ya que se genera una brecha entre la praxis y su fundamentación teórica, conceptual que, al no provenir de ella, obliga a aplicar a veces maquinal y forzadamente estudios de otras 
disciplinas para dar cuenta de un acto performativo con la justificación de que toda profesionalización debe estar acorde a los parámetros de la institución. Surgen así trabajos valiosos, a veces, para los estudios del teatro, pero poco redituables para el teatrista cuando enfrenta un proceso creativo. Es por ello que, desde la praxis teatral, involucrada en la política lacaniana, la noción de convivio, por ejemplo y tal como veremos más adelante, más bien obstruye el trabajo del teatrista que lo potencia, en el sentido de que pondría al teatrista en cierta dirección de satisfacer una demanda del público o una demanda del contexto académico y cultural.

La praxis teatral, con su base en la teatralidad concebida en una dimensión agonística, esto es, como política de la mirada, se inscribe a partir del conflicto (que usualmente compete al saber inconsciente y al poder), no de las convergencias y afinidades conviviales. Se enfoca en los antagonismos, no en las conciliaciones; se trata, como puede verse, de una diferencia política relevante. Si nos vemos obligados a cuestionar el convivio desde la praxis teatral, es precisamente para marcar la diferencia respecto a las "epistemologías" teatrales y la filosofía del teatro y el objetivo del teatrista en su trabajo. Como el teatro no es sin el público, la cuestión se nos plantea, desde los temas de este ensayo, en relación a que el convivio se inclina hacia una dimensión de homogeneidad, mientras que la praxis teatral se interesa en la heterogeneidad, tal como Laclau la correlaciona con lo real lacaniano. Para decirlo sucintamente, el convivio tiende a conceptualizar el público como masa, mientras que la praxis teatral apunta a la formación de 'pueblo' en el sentido de Laclau, como disparador de construcción de hegemonías a partir de demandas singulares insatisfechas puestas en relación equivalencial por medio de un significante vacío o flotante.

En efecto, el convivio, tal como lo ha elaborado Jorge Dubatti (2011), nos parece tomar sus credenciales genealógicas en la noción de masa tal como es descripta desde el libro de Gustave Le Bon (1841-1931), The Crowd, publicado en 1895, que llega hasta Freud y más tarde hasta los debates actuales como la aproximación de Ernesto Laclau. No es éste el lugar para cotejar exhaustivamente convivio y masa. Basta anotar un par de citas para proceder en el futuro a un trabajo más pormenorizado. Solo pretendemos aquí anotar algunas cuestiones de la noción de convivio desde la perspectiva de las disciplinas científicas en contraste con la praxis teatral, en la medida en que nos parecen relevantes al tema específico de este ensayo. Por ejemplo, Le Bon subraya la influencia y el poder que ejercen las palabras que, al desatarse el significante del significado, promueven imágenes que evocan un sentido independiente de su significado habitual (Le Bon, 2011: 60). Esas imágenes son vagas, grandiosas, oscuras y misteriosas (Le Bon, 2011: 60), porque, de alguna manera, satisfacen mítica y globalmente demandas diversas. Este poder de las palabras y las imágenes - "magical power" como lo denomina Le Bon (2011: 60), cercano al de poíesis dubattiana-se define como capaz de formar una multitud por medio de la sugestión, la imitación y la identificación. Cuando calificamos de celebratoria a esta operación de sugestión, es para indicar que ese poder mágico pareciera contener la solución de todos los problemas, promoviendo una satisfacción masiva y plena de dichas multitudes. Las palabras e imágenes sintentizan "the most diverse unconscious aspirations and the hope of their realization" (Le Bon, 2011: 60). Le Bon, además, subraya el hecho de que "The masses have never thirsted after truth" (2011:64); por el contrario, deifican la ilusión y, por ende, el error (2011: 64). Por otra parte, esas ilusiones se expanden a la manera de una infección que las afecta corporalmente: "Ideas, sentiments, emotions, and beliefs possess in crowds a contagious power as intense as that of microbes" (Le Bon, 2011: 73).

El componente de supremacía racial y el de superioridad de género no dejan de filtrarse en esta sociología, desde Le Bon en adelante: la masa responde y se somete celebratoriamente al líder, un ser superior, desde una dimensión animal marcada 
por el instinto: "Crowds instinctively recognise in men of energy and conviction the masters they are always in need of" (2011: 112). Al ser capturado por las palabras y las imágenes, el hombre se masifica al descender varios escalones en su nivel de civilización, comportándose como un bárbaro cuya violencia amenaza el orden social. Citemos este párrafo de Le Bon, ya famoso:

\begin{abstract}
Moreover, by the mere fact that he forms part of an organised crowd, a man descends several rungs in the ladder of civilisation. Isolated, he may be a cultivated individual; in a crowd, he is a barbarian - that is, a creature acting by instinct. He possesses the spontaneity, the violence, the ferocity, and also the enthusiasm and heroism of primitive beings, whom he further tends to resemble by the facility with which he allows himself to be impressed by words and images - which would be entirely without action on each of the isolated individuals composing the crowd - and to be induced to commit acts contrary to his most obvious interests and his best-known habits. An individual in a crowd is a grain of sand amid other grains of sand, which the wind stirs up at will. $(2011: 19)^{17}$
\end{abstract}

Hay un pasaje siempre al acecho del individuo cultivado a un nivel inferior instintivo, animal, salvaje. Instinto, autoridad, sugestión, imitación, identificación comienzan a ser las nociones al uso de la sociología desde Taine, Tarde, McDougall hasta Freud. Todas ellas están al servicio de una construcción de subjetividad de tipo homogéneo e indiferenciado necesario para la formación de la masa. La cuestión pulsional como afectación del cuerpo no se hace esperar. Hay, pues, una presencia corporal física de esos integrantes de la multitud quienes, al hacerse masa, constituyen un peligro para la sociedad, el cual requiere de un estudio científico para apuntalar el control disciplinario del Estado. Como vemos, algunas de estas nociones (sugestión, imitación, identificación) no están lejanas de nuestro vocabulario teatral corriente, incorporadas asistemáticamente a técnicas actorales y metodologías teatrales diversas. Gabriel Tarde ya discierne el contraste entre las multitudes y los públicos y eso está pendiente de una revisión en nuestra praxis teatral porque, como el convivio, multitudes y públicos se orientan hacia una "lógica de la homogenización" (Laclau, 2014: 68).

\section{Acto y sujeto versus subjetividad y experiencia}

Pues bien, acerquemos ahora a este breve cotejo, algunas afirmaciones de Dubatti en su libro Introducción a los estudios teatrales:

Al menos dos tipos de definición expresan la especificidad del teatro: una definición lógico-genética, como acontecimiento triádico, y una definición pragmática, como zona de experiencia y construcción de subjetividad. Según la redefinición lógico-genética, el teatro es la expectación de poíesis corporal en convivio; según la definición pragmática, el teatro es la fundación de una peculiar zona de experiencia y subjetividad en la que intervienen convivio-poíesis-expectación. (2011:34)

Retengamos de esta cita, en principio, tres cuestiones: la zona de experiencia, la construcción de subjetividad y la presencia de lo corporal: el teatro como acontecimiento y experiencia que afecta los cuerpos construye subjetividades. Ya hemos hecho mención a la experiencia, como base de la profesionalización y como opuesta al acto performativo. Una experiencia es, como dice el diccionario de la RAE, una memoria de haber sentido, conocido o presenciado algo, una "práctica prolongada que proporciona conocimiento o habilidad para hacer algo". Está, pues, del lado de la rutina y del oficio, exactamente como opuesta al acto, siempre nuevo, incierto y desafiante del conocimiento, porque se origina en el no-saber y solo se juzga por sus consecuencias. Nos dice Dubatti:
17. “Además, por el mero hecho de que forma parte de una multitud organizada, un hombre desciende varios peldaños en la escala de la civilización. Aislado, él puede ser un individuo cultivado; en una multitud, él es un bárbaro, es decir, una criatura que actúa por instinto. Él posee la espontaneidad, la violencia, la ferocidad y también el entusiasmo y el heroísmo de los seres primitivos, a quienes además tiende a parecerse por la facilidad con la que se deja impresionar por palabras e imágenes-las que carecerían completamente de acción en cada uno de los individuos aislados que componen la multitud-y ser inducido a cometer actos contrarios a sus intereses más obvios y sus hábitos más conocidos. Un individuo en una multitud es un grano de arena entre otros granos de arena, que el viento agita a voluntad" (mi traducción). 
Llamamos convivio o acontecimiento convivial a la reunión, de cuerpo presente, sin intermediación tecnológica, de artistas, técnicos y espectadores en una encrucijada territorial cronotópica (unidad de tiempo y espacio) cotidiana (una sala, la calle, un bar, una casa, etcétera, en el tiempo presente). (2011: 35)

No se plantea el saber sobre el deseo de un sujeto particular, sino que se pluraliza en la medida en que el teatro fabrica subjetividades que intervienen en la vida cotidiana. Notamos también un proceso de transformación-de tipo ontológico, ya no de descenso en la escala civilizatoria - que pasa del individuo común al de miembro del público, al entrar en contacto presencial con la poíesis, las palabras y las imágenes.

No somos los mismos en reunión puesto que establecemos vínculos y afectaciones conviviales, incluso no percibidos o conscientizados. En el teatro se vive con los otros: se establecen vínculos compartidos y vínculos vicarios que multiplican la afectación grupal. (2011: 35)

Lo que la praxis teatral, como disciplina en constante formación, podría objetar aquí es la cuestión de la construcción de subjetividades. Jorge Alemán, precisamente en su libro Horizontes neoliberales en la subjetividad, investiga cómo la sociedad capitalista neoliberal ofrece repertorios de subjetividades que excluyen, borran al sujeto del inconsciente. Ya mencionamos el ejemplo sartriano. Por su parte, Walter Benjamin, yendo un poco más lejos que la tesis de Weber, planteaba en 1921 al capitalismo como un parásito del Cristianismo en las sociedades occidentales, pero además ya anunciaba su carácter destructivo, destructivo del sujeto, sin duda: "Capitalism is entirely withouth precedent, in that is a religion which offers not the reform of existence but its complete destruction" "Capitalism as Religion" 1996: 289). Es importante remarcar este aspecto, porque hace al núcleo mismo de la diferencia entre estudios teatrales y praxis teatral con fundamentos psicoanalíticos. Tenemos que detenernos un momento siquiera en ello porque constituyen el punto de convergencia problemático en el psicoanálisis, en la praxis teatral y en la academia.

Jorge Alemán plantea la necesidad de "diferenciar al sujeto de la subjetividad", porque se trata de "una diferencia política clave" (2016: 109). Es una diferencia, según Alemán, que divide aguas: por el lado del inconsciente, es decir, del psicoanálisis, tenemos el sujeto (dividido); por el lado de la filosofía, tenemos plenitud de consciencia yoica o cartesiana (incluso con matices fenomenológicos) que remiten a las subjetividades y, por esa vía, a la negación del sujeto. Según este autor, tendríamos al menos tres izquierdas: una izquierda clásica, de corte marxista, para la que habría un sujeto histórica capaz de llevar a cabo la revolución y superar el capitalismo. Se trata de una "versión teleológica de la historia" (Alemán, 2016: 110) que las derrotas de la izquierda desde mediados del siglo XX ya demostraron con su ineficacia, precisamente por sus encuadres verticalistas y sus vanguardias lúcidas ancladas en el discurso del Amo. Luego, apareció una izquierda postmoderna, "que pensó las relaciones de poder como aquellas relaciones históricas construidas por distintas formas de poder" (Alemán, 2016: 109). Aparecen así las subjetividades (feminista, gay, queer, terrorista, inmigrante, narcotraficante, etc.), como "efecto de las relaciones de poder construidas [esto es] históricamente, generada[s] por dispositivos, producida[s] por tecnologías" (Alemán, 2016: 109-110). Finalmente, tendríamos la izquierda lacaniana cuyo punto de partida es el sujeto del inconsciente, la subversión del sujeto cartesiano o el parlêtre. En ella no se trata de describir subjetividades y menos aún de proponerlas para que los sujetos se reconozcan en ellas, se sometan a ellas, se identifiquen en y con ellas, sino de promover la emancipación del sujeto de su alienación al goce del Otro (incluso el encapsulado en esas subjetividades institucionalizadas surgidas de movimientos reivindicatorios de las diferencias); la izquierda lacaniana apunta a la singularidad del sujeto, a aquello que Alemán denomina "lo inapropiable" (Alemán, 2016: 115) 
para el Neoliberalismo y que, por su carácter inconsciente, configuraría una brecha, una ruptura capaz de obstaculizar el poder circular y continuo de la reproducción capitalista neoliberal. Para Alemán se trata de la tarea política fundamental que hoy habría que explorar: para construir hegemonía frente a ese Otro enemigo que no satisface las demandas populares, hay que investigar el lugar del sujeto, definirlo, pues "el hecho político contemporáneo pasa por definir qué es el sujeto, que ya no se puede hacer política solo definiendo leyes objetivas de lo social, o comportamientos de las distintas clases" (Alemán, 2016: 124).

La producción de subjetividad, más allá de las iniciales intenciones de la izquierda postmoderna, fue capturada por el discurso capitalista, particularmente en su versión neoliberal; su propósito es "fabricar subjetividades" (Alemán, 2016: 111), darlas como 'ready made', hacerlas sostener por el discurso de la Universidad, darles curso de circulación social como Ideales con la consecuencia ineludible de promover progresivamente la destrucción del sujeto y, por ende, deteriorar el lazo social, destruyendo los semblantes que lo sostienen. ¿Qué significa esto? Significa que el sujeto dividido, dividido por el lenguaje como fundamento del contrato social y como operador de la falta que es el deseo, queda a merced del goce obsceno del superyó-mercado, condenado a producir ya no solamente mercancías sino "plus de goce", y atravesado por la pulsión de muerte. Ya no se trata, para Alemán, del empleado que produce plusvalía, sino del "in-empleado" que produce plus de goce, un excedente de goce originado en su situación de precariedad y de exclusión del sistema, que ya "no tiene lugar ni tendrá lugar en el Otro" (Alemán, 2016: 112), con la consecuencia de verse necesitado, a causa de la "acumulación de desposesión" (Alemán, 2016: 130), de aceptar cualquier tipo de reclutamiento letal por el narcotráfico, el terrorismo, la burocracia. El egoísmo del individualismo capitalista se torna ahora, en la etapa neoliberal, contra el individuo mismo: interesado a tal punto en "el mal de los otros", llega al extremo del goce mortífero cuando "es capaz de hacerse un daño que lo extinga con tal de que los otros se perjudiquen para siempre” (Alemán, 2016:113). Como vemos, el lazo social queda arrasado por estas subjetividades sin sujeto dividido, sin deseo; sin freno de ley alguna, estas subjetividades comienzan a moverse maquinalmente y quedan capturadas por el superyó que impone gozar, que deja al sujeto desamparado frente a lo pulsional con base en lo corporal. Al no haber, entonces, un exterior al discurso capitalista, se van deshaciendo las oposiciones civilización-barbarie, democraciaterrorismo (Alemán, 2016: 115). Por eso mismo, si el psicoanálisis y la praxis teatral tienen todavía un campo de intervención, es justamente porque apuntan al sujeto, al inconsciente, como instancia de lo inapropiable por el sistema. A su manera, Dubatti aborda esta cuestión de plusvalía capitalista:

Dentro del convivio y a partir de una necesaria división del trabajo, se producen los otros dos subacontecimientos, correlativamente: un sector de los asistentes al convivio comienza a producir poíesis con su cuerpo a través de acciones físicas y físico-verbales, en interacción con luces, sonidos, objetos, etcétera; mientras, otro sector comienza a expectar esa producción de poíesis. Se trata respectivamente del acontecimiento poiético y del acontecimiento de expectación. (2011: 37)

Esta división del trabajo, sin embargo, de acuerdo a este banquete convivial, no oculta tres aspectos ya señalados por Le Bon para la masa: el "poder mágico", su carácter contagioso y la afectación corporal. "Llamamos poíesis -escribe Dubatti-al nuevo ente que se produce, y es, en el acontecimiento a partir de la acción corporal" (2011: 38). Si por un lado pareciera enfatizar el aspecto pulsional desde la acción corporal-que ya insinúa un plus de goce-por el otro aplasta la cuestión del sujeto y del inconsciente cuando afirma que " $[\mathrm{e}] 1$ acontecimiento de expectación implica la consciencia, al menos relativa o intuitiva, de la naturaleza otra del ente poético" (2011: 39, mi énfasis). Para evitar el efecto directo de construcción de masa, se recurre al 
yo, a la conciencia, capaz de discernir entre ficción y "realidad" mediante la instalación de una distancia ontológica que, por otra parte, no se sabría de dónde o bajo qué circunstancias estructurales podría ocurrir ese 'salto': "No hay expectación sin distancia ontológica, sin consciencia del salto ontológico o entidad otra de la poíesis" (2011: 39). Y agrega: "la función primaria de la expectación - observar la poiesis con distancia ontológica, con consciencia de separación entre el arte y la vida-para que el trabajo del espectador se realice" (2011: 41).

La praxis teatral pregunta: ¿desde qué punto el público podría separarse ${ }^{18}$ ¿Qué agencia podría asistirlo para esa operación? ¿Cómo se las arreglaría el público para distinguir arte y vida, ficción y realidad, si convenimos en que la construcción de realidad es imaginaria, a nivel social y también individual, lo que -como se ve-complejiza el planteo en la medida en que habría múltiples versiones sectoriales y particulares de esa 'realidad' ilusoria? El carácter de sugestión, identificatorio, contagioso, no se hace esperar: "La expectación no se limita a la contemplación de la poíesis, sino que además la multiplica y contribuye a construirla" (2011:42). Y, en consecuencia, la homogeneidad buscada se celebra en ese convivio entre artistas y público, sin diferenciación y sin mayor perspectiva de construcción de hegemonía en el sentido de Laclau, en la medida en que disuelve los antagonismos: "El teatro es un lugar para vivir - de acuerdo al concepto de convivio y cultura viviente-, la poíesis no sólo se mira u observa sino que se vive. Expectación, por lo tanto, debe ser considerada como sinónimo de vivir-con, percibir y dejarse afectar en todas las esferas de las capacidades humanas por el ente poético en convivio con los otros (artistas, técnicos, espectadores)" (2011: 42). Sin embargo, de pronto, como entre bambalinas, se percibe la presencia de un Otro, sin el cual la relación diádica entre escena y público caería, por decir lo menos, en el embotamiento narcótico típico de la masa: "La distancia ontológica respecto del ente poético es un saber adquirido históricamente: el espectador va tomando consciencia de la naturaleza del ente poético a partir de su frecuentación y su contacto con el teatro. Por su naturaleza dialógica y de encuentro con el otro, el teatro exige compañía, amigabilidad, disponibilidad" (2011: 42). No se sabe aquí porqué caminos deductivos Dubatti llega a la conclusión de que "el teatro exige compañía, amigabilidad, disponibilidad" a partir de las premisas que él mismo ha puesto a su silogismo. Tomar conciencia del ente poético (incluso si eso se produce) no implica celebración conciliatoria convivial; podría haber una contingencia de violencia y desacuerdos, antagonismos impredecibles. Vemos, pues, que la apelación al registro simbólico de las convenciones es a lo que Dubatti recurre para resguardar su convivio de las consecuencias poco conviviales causadas por ese poder contaminante y ese plus de goce incitados por las palabras e imágenes de la poíesis.

Frente a este panorama, resulta evidente la dirección opuesta que toma la praxis teatral: en primer lugar, porque apunta al sujeto, al inconsciente, para explorar esa dimensión de lo inapropiable, la cual, obviamente, nada tiene que ver con representar la realidad sino inventarle significantes a eso Real que constituye el malestar en la cultura; en segundo lugar, porque apunta al deseo, en tanto singular, para desactivar la captura del sujeto del goce letal promovido por el capitalismo neoliberal y la captura del sujeto por las subjetividades fabricadas. La praxis teatral, basada en la concepción lacaniana de que toda comunicación es un malentendido, se preocupa no por la homogeneidad del público en convivio, sino por la heterogeneidad de demandas particulares de cada miembro de ese público para invitarlo, a través de espectáculos enigmáticos (pero no crípticos ni con mensajes empaquetados) a interpretar y hacer sentido, abriendo la posibilidad de establecer relaciones equivalenciales capaces de construir, más allá del teatro, hegemonía promotora de actos instituyentes en el contexto social. La praxis teatral pone a trabajar al Amo, al público. No alienta comunión, sino debate, polémica, en el sentido etimológico de la palabra como 'arte de la guerra' del cual, como aprendimos en Clausewitz, la política es su versión en tiempos
18. Para un desarrollo más detallado de los conceptos lacanianos de alienación-separación, ver mi "Dramaturgia de frontera/dramaturgias del crimen"(2018) 
pacíficos. El arte tiene la función ineludible de experimentar con invenciones para lo real que puedan, a la postre, contribuir a demarcar fronteras para que jueguen los antagonismos. Pluralizar, más que converger o coincidir. No es trabajo político de la praxis teatral propender a consolidar mensajes doctrinarios, porque al partir del no-saber, parte de la misma dimensión en la que el público debate sus insatisfacciones; porque al carecer de una verdad, evita toda dimensión autoritaria, incluso bajo las mejores intenciones y los velos de lo sugestivo. Enfrenta, pues, las subjetividades circulantes para abordar la forma en que destruyen el sujeto y lo hace a riesgo de una inmersión en aquellas zonas de lo políticamente incorrecto: como lo plantea Miller, "[1]a política lacaniana es una cierta política de la insistencia, la insistencia en hacer salir al deseo oculto tras las buenas razones y la buena intención" (104). Y ello es así porque, interesada en el saber inconsciente, "que no es desconocimiento ni ignorancia, es un saber en reserva que en cualquier momento puede aparecer en cualquiera y dar paso a una verdad política" (Alemán, 2016: 139), dicha política lacaniana no se apoya en los conocimientos ya adquiridos, salvo temporariamente para desafiarlos, cuestionarlos y, a veces, desestabilizarlos.

\section{El saber-hacer del teatrista}

Con este instrumental conceptual podemos aproximarnos a cuestiones que competen al trabajo del teatrista. Todo espectáculo se organiza a partir de demandas, sean las de los teatristas, sean las del público. Y esto equivale a decir que responden a insatisfacciones diversas cuyo origen hay que plantear desde la perspectiva mítica y desde la perspectiva de la heterogeneidad, ambas íntimamente conectadas a ese malestar en la cultura, a ese real y goce que carece de palabras y que, por ser inconsciente, escapa a nuestra dimensión yoica, nuestra conciencia. No se trata, como vemos, de trabajar sobre ideas que circulan en el campo social (feminismo, reclamos por derechos humanos, por la legalidad del aborto, por la esclavitud contemporánea, por la destrucción del medio ambiente, por los horrores de las diásporas migratorias en el capitalismo neoliberal, etc.) y que el teatro debería ilustrar para permitir una toma de conciencia cuyo resultado más optimista sería la construcción de hegemonía de esos sectores insatisfechos. Para un teatrista interesado en lo artístico, la tarea, como es de suponer, es mucho más compleja, porque él o ella nada saben de ese real; solo conoce la información circulante, experimenta los mismos horrores que su comunidad en su propio cuerpo o responde a demandas institucionales progresistas. Un teatro de arte no es un teatro promocional de una agenda política o cultural; entendemos aquí al teatro de arte como el que no se interesa en ilustrar/decorar ideas sobre la escena, sino en abordar, desde el cuerpo mismo del teatrista, lo real de ese goce que también lo marca y del que nada sabe. Es decir, en primer lugar, trabajar la consistencia de su propia demanda. ${ }^{19}$ Aunque podemos tener un conocimiento más o menos detallado de las tendencias teatrales más favorecidas por el público, nunca podemos precisar puntualmente cuál es el real que finalmente ancla en la demanda de cada uno de los miembros de ese público. No olvidemos, además, que la demanda hace puente con el deseo -de los teatristas, del público-del que, por ser inconsciente, nada sabemos. ¿Cómo abordar el trabajo del teatrista, desde su inicial impulso de creatividad, de selección de materiales, de trabajo con el grupo, de su propuesta de teatralidad, etc.?

Si las categorías que hemos considerado pueden ayudar aquí, al menos sabemos que múltiples factores van a converger desde los inicios mismos del trabajo. Vamos a atenernos en este ensayo en la cuestión de la demanda y el rol 'político' del teatro (no de la política y menos de la política del teatro). Por lo pronto, aspiramos a un espectáculo capaz de aportar, desde el no sentido, desde lo ambiguo o el equívoco, desde la contingencia, la posibilidad de que, por un lado, el grupo teatral y, por otro,
19. En mi Dramaturgia de frontera/ dramaturgias del crimen (2018) relato el proceso de trabajo en Las mujeres de Juárez del mundo. Allí los estudiantes/actores vinieron con una demanda precisa, trabajar sobre este tema $\tan$ siniestro y que tanto los afectaba. Desde mi posición analítica, me negué a satisfacer esa demanda de trabajar sobre ese "tema". Les propuse una dinámica diferente en la que, paulatinamente durante los ensayos, ese 'siniestro' era parte de sus propios cuerpos y por eso trabajamos a partir de ese real. 
el público, conformen cadenas equivalenciales alrededor de significantes vacíos o significantes flotantes capaces de poner esas demandas democráticas, diferenciales, en una relación de equivalencia. Así, aunque apuntemos a brindar un significante vacío o flotante que dispare la construcción hegemónica, nuestro espectáculo debe circunscribirse a ser ese acontecimiento instituyente y no pretender convertirse inmediatamente en lo instituido. ${ }^{20} \mathrm{Al}$ instituirse, se produce inevitablemente el pasaje a la posibilidad de una acción hegemónica, que debería ser el límite, la frontera frente a los que el teatro de arte (no todo el teatro) debe detenerse. Esa posibilidad de movilización instaurada como antagonismo frente a un otro ubicado del otro lado de la frontera (Estado, instituciones diversas, líderes) es algo que puede resultar como efecto de un espectáculo, pero el acto instituyente teatral no debería como tal cancelar su potencial creativo convirtiéndose en apéndice o representante de los procesos de reclamo a los que, obviamente, puede acompañar. En todo caso, esa tarea queda para otras agencias comunitarias en su lucha por la hegemonía y la satisfacción de sus necesidades.

El público asiste por una demanda y hasta paga para ser satisfecho. ¿Deberíamos satisfacer esa demanda? ¿Podemos satisfacerla realmente? El teatro comercial sabe cómo satisfacer esas demandas, aunque a veces pueda fallar. Muchas veces el teatro comercial, como ligado al consumo, genera artificialmente una demanda que, luego, satisface y el público, por lo tanto, alcanza la plenitud mítica de su felicidad, como cuando un analista no lacaniano declara "curado" a su paciente porque ahora se ha adaptado correctamente a los mandatos sociales, al goce del Otro o a la imagen de su analista. ¿Procederá el teatro de arte de la misma manera? Dejemos de lado las veleidades narcisistas, que nunca faltan, a veces bajo la forma de pretensiones rupturistas o vanguardistas, de exhibicionismo puro, para las cuales el grado de incomprensión del público satisface la demanda de identidad del teatrista construida sobre la mera transgresión. El teatro comercial y el teatro rupturista ofician como dos polos contrapuestos respecto a la forma en que se posicionan respecto de la demanda del público. De maneras diversas, cada uno trabaja desde la sugestión y propone identificaciones.

Ahora bien, como cada miembro de ese público tiene una demanda singular, el efecto político del teatro debería residir precisamente en poder articular ese significante vacío o flotante que las pone en equivalencia para iniciar un proceso de lucha. El teatro de arte no debería proponerse, con o sin Brecht, adoctrinar ocupando el discurso del Amo o el discurso de la Universidad, a la manera de quien tiene la verdad y la propone (o impone) para generar identificaciones, conciliaciones, adhesiones o sometimientos; ese tipo de subjetividades producto de identificaciones a Ideales del yo propuestos por un teatro en posición de Amo, generan masa (convivio) y no pueblo, en el sentido que le da Laclau en La razón populista. En todo caso, el teatro de arte debería mantenerse en un trabajo con lo real para hacer emerger un significante tal que pueda permitir poner en una misma línea de equivalencia las demandas singulares temporariamente. Cada miembro del público resignará algo de su demanda en beneficio de una relación equivalencial que permita, ya fuera del espectáculo, la movilización y el reclamo. Y esto no es un convivio, una celebración; es una estrategia política precisa, con antagonismos específicos sin los cuales no hay pueblo.

Como vimos, desde esta perspectiva, el teatro no puede convertirse en una excusa para ilustrar ideas; tiene que mantenerse en la posición histérica de un constante dudar y cuestionar al Otro (del poder) o bien mantenerse éticamente en la posición del analista que suspende su saber y no legisla sobre el bien del otro. Obviamente, el teatro comercial y el llamado teatro político (como ocurrió con la creación colectiva de los años 70), proponen significantes-amo que operan como Ideales del yo y hablan desde el lugar de una verdad que no necesariamente es la del público; genera debate, incluso distanciamiento crítico, en todo caso, pero no genera un espacio para que
20. Los grupos teatrales que, a veces convocados alrededor de la figura de un maestro, se han instalado como lo instituido, corren el peligro de limitar su potencial creativo y crítico al convertir su dinámica artística en algo ortodoxo incapaz de deconstruirse y avanzar hacia nuevos desafíos artísticos. 
se constituyan contingentemente cadenas equivalenciales; por el contrario, si estas cadenas se instalan, lo hace por sugestión e identificación, esto es, por coerción autoritaria desde el escenario. De modo que la consistencia del espectáculo, tal como lo entiende la praxis teatral, no puede ser coherente, con mensaje transparente, sino por el contrario ambiguo, impreciso respecto a la relación significante/significado, equívoco, para que la comunidad interprete por sí misma cómo proceder a partir de ellos, cómo organizar una demanda popular a partir de un significante vacío o flotante que le resulte específico para sus reclamos.

No es al teatro al que se le hacen reclamos por el aborto, por la violencia doméstica, por la pobreza, por el abuso a los derechos humanos, es al Otro, sea el Estado o los representantes democráticos que supuestamente deberían ocuparse de esas agendas. Pero el teatro, no obstante, puede afrontar esas demandas proveyendo al público la posibilidad de articular ese significante vacío o flotante necesario para la movilización política, para la construcción de hegemonía... fuera del teatro y a partir de aquello real, de aquel goce que constituye lo inapropiable.

\section{A manera de conclusión temporaria}

El concepto psicoanalítico de "sobreinvestimiento" nos resulta aquí útil en la medida en que nos permite distinguir al menos dos tipos de trabajo en el campo de la praxis teatral. Es innegable que el público, frente a un espectáculo enigmático-diferente a un espectáculo críptico, que obtura toda posibilidad de interpretación - se ve necesitado de interpretarlo, de trabajar su propio discurso frente a lo dado-a-ver. Es un espectáculo que lo saca de la zona de confort típica del ofrecimiento del teatro comercial, o de la zona de goce absoluto del teatro vanguardísticamente radical, ambos culturalmente necesarios. De dicho espectáculo, como vimos, puede resultar un significante vacío o flotante que pone en cadena equivalencial una serie de demandas insatisfechas, sin promover identificaciones a un significante preciso, sobreinvestido por el teatrista, tal como ocurre con el llamado teatro político. Lo político de esta nueva perspectiva teatral, sea el teatro de la intensidad o de la multiplicidad o cualquier otra manifestación que se elabore a partir del no saber, del sinsentido, de lo Real, reside en su capacidad de dinamizar al público, hacerlo trabajar y no meramente darle servido una supuesta solución social a sus problemas. Por eso mismo, es poco probable que este tipo de propuesta pueda apelar a los recursos "aristotélicos", ya que la trayectoria edípica que la funda (secuencia comienzo-nudo-desenlace, catástrofe, justicia poética, piedad y temor, etc.) resulta difícil (aunque no imposible) para disparar instancias de interpretación más emancipadas. Recordemos aquí que el trabajo con la demanda supone dos cosas: por una parte, un trabajo con la resistencia del público, que es siempre resistencia al deseo del analista -el teatrista en nuestro caso- que quiere imponerle ciertos significantes; por la otra, que la resistencia mayor está del lado del teatrista.

Ya vimos el fracaso de este tipo de experiencias teatrales coercitivas en el siglo XX. Un teatro comercial o político parte de ideas, las ilustra con una fábula, propone un significante-amo que daría solución a los males sociales y pretende la aceptación consensual, convivial del público convertido en masa y que contemplativamente expec$t a$, por identificación al escenario y a la propuesta que le ha sido presentada. Es una forma celebratoria que, como se vio en los estudios sobre la formación de masa desde Le Bon hasta Freud, procede por identificación al líder (la escena o el maestro) y la identificación de los yoes de cada cual entre sí en la masa. Justamente el efecto que se produce es la dependencia y la obediencia a esa idea, pero no la promoción de un significante vacío o flotante capaz de construcción de hegemonía. El líder, se supone, es capaz de iluminar cuál es el bien para la comunidad e instaura, ineludiblemente, un aparato de disciplina y control (que, históricamente, como sabemos, no ha 
ahorrado violencias de todo tipo) para asegurarse de ser capaz de satisfacer la demandas a nivel total y global, algo obviamente imposible. Sin duda, hay un momento de celebración cuando esto ocurre, en la medida en que pareciera fundarse un instante de reconciliación de las diferencias comunitarias, encarnada en la figura del líder y la plenitud de la satisfacción mítica; es un instante de pacificación y plenitud que solo puede mantenerse por el recurso a la violencia (represión, control, censura, persecución, etc.). No abre un espacio de debate comunitario para que la comunidad se posicione, errada o no, como agente de su propio destino. ${ }^{21}$

Así, si el teatrista parte de sobreinvestir con una catexis suplementaria un significante específico (feminista, postcolonial, subalterno, queer, etc.) ya catectizado en lo social, consolidando su relación significante/significando, no puede evitar ocupar la posición de Amo (o el deseo de serlo), legislando lo que es lo mejor para el público y pretendiendo adhesiones críticas o espontáneas que, a su vez, lo confirmen en su poder. Al proceder de esta manera, no abre el camino a las interpretaciones o el debate, sino que espera conciliación y acatamiento. La frontera de los antagonismos que, según Laclau, es indispensable para la emergencia del 'pueblo', no surge en estos casos del trabajo del público en relación a la propuesta enigmática de la escena, sino que es ya impuesta por la posición misma del teatrista y su espectáculo. Si el teatrista, en cambio, desamarra el significante del significando, lo vacía, lo torna flotante, se abstiene de proponer, para sí mismo y para el público, un espectáculo dado-a-consumir, con un mensaje, como un mensaje, tal como ocurre en el teatro 'tradicional'; abre el debate sin legislar, dejando al público confrontar sus diferencias y discernir la posibilidad de un punto de equivalencia en algún significante que proceda de su propia deliberación y que le permita, fuera del teatro, construir hegemonía mediante la demarcación de una frontera no impuesta por otro, sino por su propia polémica.

Cuando planteamos que el teatrista se abstenga de proponer significantes-amo, para sí mismo y para el público (salvo cuando ya sea 'su' público, como algo institucionalizado, para el que solo vale reafirmar posiciones más que desestabilizarlas), no queremos insinuar que deba ponerse en un afuera de los social. Lo que plantamos es la posibilidad de que el teatrista se ponga fuera de la conciencia, de la suya, fuera del mercado, y permita un trabajo con lo inconsciente, para precisamente aportar una significantización a lo Real, aquello del malestar en la cultura que no tiene aún verbalización y que, obviamente, no la tendrá nunca completamente. Estamos así no en el campo del discurso del Amo con su pretensión de verdad única, universal, ilusoriamente completa, total o totalitaria, sino en el del semblante de la verdad, en el mediodecir de la verdad sobre el goce y lo real. El teatrista, por lo tanto, tiene como tarea sobreinvestir no aquello que sabe, no aquello que está en el domino del yo y de la conciencia, sino confrontarse con el enigma, el sinsentido porque éste, sin dudas, es el que está operando a nivel inconsciente. Y si el inconsciente, tal como Lacan lo planteara, no es colectivo sino transindividual, si el inconsciente es el discurso del Amo con el que tenemos que vérnosla (Miller, 2017: 98), si "el acto es trans-individual" (Miller 98), si es particular para una comunidad, histórico, no universal, no atemporal, entonces es factible que, en algunos casos, el espectáculo producto de ese trabajo pueda hacer puente con aquello que también afecta a la comunidad donde dicho trabajo se efectúa y para la cual se efectúa.

Partir de una idea, por más políticamente correcta que se la quiera, es en general la partida de defunción anticipada para un teatro de arte (no, obviamente, para un teatro en posición de Amo). Supone legislar anticipadamente sobre el deseo de los demás; vender, incluso, un producto porque se supone que responde a una demanda. Lacan nos advirtió que el analista no debe responder a la demanda. Toda demanda es demanda de amor, es decir, que una vez satisfecha una necesidad, puede quedar activa la demanda (incluso por el reconocimiento). Aquello que queda como residuo
21. En mi libro Dramaturgia de frontera/dramaturgias del crimen (2018), hago mención a los levantamientos iniciados por las mujeres en la meseta Purépecha del Estado de Michoacán de Ocampo, en que el grupo indígena predominante, desde el 15 de abril de 2011, establece el Autogobierno del Municipio de Cherán (55-56); ejemplo alentador de cómo se evitó la formación de masa y se construyó hegemonía. 
es el deseo, indestructible por lo demás, del que nada se puede saber y menos por anticipado. Responder a la demanda significa que el teatrista está en posición de dar lo que al otro le falta. Pero como la falta del otro se registra a nivel de su deseo, y nadie tiene ese objeto perdido y singular para ese sujeto, resulta que, si el teatrista lo intenta, incluso bajo la forma de proponerse como Ideal del yo a imitar por el público, lo único que produce es una réplica de sí mismo, basada además en supuestos valores asumidos como benéficos para el otro. Otra vez masa, otra vez convivio, falta de antagonismo, celebración, sumisión. Queda, en esta operación, completamente aplastada la singularidad del sujeto.

Lo mismo podríamos plantearnos a partir de la praxis teatral respecto al espectáculo y, por una vía indirecta, a la aproximación crítica y académica. En efecto, el llamado teatro político, con o sin distanciamiento crítico, lleva la crítica solo al campo de las adhesiones, proponiéndose como capaz de iluminar al público en aquello en que éste estaría completamente engañado o confundido. Es decir, responde a la demanda. En el caso de la academia, además, se responde a demandas institucionales que garantizarían la estabilidad laboral y obviamente la circulación de un conocimiento consolidado por múltiples factores de poder y reconocimientos. Un círculo vicioso similar ocurre con el teatro: sabemos cómo asiste a este tipo de espectáculos gente que se identifica con una propuesta y el teatrista entonces no puede más que satisfacerlo, como en cualquier otro teatro comercial. Elabora un producto para esa demanda sobre valores que supuestamente son los idóneos para ese público y que, por espectáculos anteriores, ese público acató por identificación. Se instala un circuito que cancela la creatividad o la subsume en meras variaciones formales, sin apuntar a cuestionar la consistencia de esos valores que supuestamente 'valen'. No produce separación de los Ideales, sino alienación a los mismos. Recordemos que la emancipación nunca termina. Ese teatro no brinda la posibilidad del debate para promover la construcción de hegemonía, sino que masifica, ofreciendo un repertorio de recetas, estereotipos, repertorio de subjetividades ya ready made, bibliografías prestigiadas, sean éstas basadas incluso en las mejores intenciones o las mejores lecturas del feminismo, de los estudios subalternos o postcoloniales, de la teoría queer, etc. Por esto mismo, es importante moverse al campo del deseo sin pretender satisfacer la demanda, ya que al hacerlo, al menos nos queda la certeza de estar trabajando a nivel de un inconsciente que, siendo transindividual, nos involucra con el público, con las incertidumbres y malestares de la comunidad. Y para trabajar a partir del deseo, hay que hacerlo a partir de aquello que está fuera del sentido, de lo simbólico, de ese famoso "coágulo" del que hablaba Eduardo Pavlovsky (2001: 103). 


\section{Dibliografia}

》Abad, G. (2016). Escena y escenarios en la transferencia. Buenos Aires/Los Ángeles: Argus-a Artes y Humanidades/Arts \& Humanities.

"Alemán, J. (2016). Horizontes neoliberales en la subjetividad. Buenos Aires: Grama Ediciones.

"Bachelard, G. (2000). La formación del espíritu científico. Buenos Aires: Siglo XXI Editores.

"Benjamin, W. (1996). "Truth and Thruths / Knowledge and Elements of Knowledges". En Selected Writings. Vol. 1 1913-1926. Cambridge, MA \& London: The Belknap Press of Hardvard UP. 278-279.

" Benjamin, W. (1996). “Capitalism as Religion”. En Selected Writings. Vol. 1 19131926. Cambridge, MA \& London: The Belknap Press of Hardvard UP. 287-291.

»Dubatti, J. (2011). Introducción a los estudios teatrales. México: Libros de Godot,. https://formaciondanzacontemporanea.files.wordpress.com/2013/05/dubattiintroduccic3b3n-a-los-estudios-teatrales-1.pdf

" Geirola, G. (2017). “El bifurcado camino de la melancolía: la civilización del espectáculo y el futuro del teatro latinoamericano". Encinas, Percy (ed.) Puesta en Escena y otros problemas del teatro. Lima: Escuela Nacional Superior de Arte Dramático. 81-118.

» Geirola, G. (2013). "Praxis teatral y puesta en escena: la psicosis como máscara espectatorial en el ensayo teatral ( $2^{a}$ parte)". telondefondo Revista de teoría y crítica teatral 9.18. http://www.telondefondo.org/numero18/articulo/487/praxisteatral-y-puesta-en-escena-la-psicosis-como-mascara-espectatorial-en-el-ensayo-teatral-2-parte-.html

" Geirola, G. (2013). "Praxis teatral y puesta en escena: la psicosis como máscara espectatorial en el ensayo teatral (1ํㅡ parte)”. telondefondo Revista de teoría y crítica teatral 9.17. http://www.telondefondo.org/numeros-anteriores/numero17/ articulo/464/praxis-teatral-y-puesta-en-escena-la-psicosis-como-mascara-espectatorial-en-el-ensayo-teatral-1-parte.html

" Geirola, G. (2017) “Praxis teatral. Saberes y enseñanza. Reflexiones a partir del teatro argentino reciente". Buenos Aires/Los Ángeles: Argus-a Artes y Humanidades/Arts \& Humanities.

" Geirola, G. (2017). “Una posible genealogía de lo político teatral: El régimen de verdad de la escena teatral." Revista Artescena (Chile) 3 (Mayo): 13-41. http:// www.artescena.cl/una-posible-genealogia-de-lo-politico-teatral-el-regimende-verdad-de-la-escena-teatral/

" Geirola, G. (2012). "El director y su público: la puesta en escena y las estructuras espectatoriales." telondefondo Revista de teoría y crítica teatral 8.15. http:// telondefondo.org/numero15/articulo/403/el-director-y-su-publico-la-puestaen-escena-y-las-estructuras-espectatoriales.html

" Geirola, G. (2011-2012). "Los cuatro discursos lacanianos y las dramaturgias." Argus-a Vol. 1 No. 2 (Diciembre /Enero) http://www.argus-a.com.ar/ensayosessays/195:los-cuatro-discursos-lacanianos-y-la-dramaturgia.html

" Geirola, G. (2018). Dramaturgia de frontera/Dramaturgias del crimen. Buenos 
Aires-Los Angeles: Argus- $a$.

» Lacan, J. (1976). Seminario 24 L'insú..., inédito, clase del 16 de noviembre.

»Lacan, J. (2002). “La dirección de la cura y los principios de su poder”. En Escritos 2. Buenos Aires: Siglo XXI Editores, 559-615. Versión francesa en http:// ecole-lacanienne.net/wp-content/uploads/2016/04/1958-07-10.pdf

»Lacan, J. (2012). “Proposición del 9 de octubre de 1967 sobre el analista de la Escuela”. En Otros escritos. Buenos Aires: Paidós,261-277.

»Lacan, J. (2006). Seminario 23 El sinthome. Buenos Aires: Paidós.

»Laclau, E. (2014). La razón populista. Buenos Aires: Fondo de Cultural Económica.

"Le Bon, G. (2001). The Crowd. A Study of the Popular Mind. Kitchener: Batoche Books. https://socialsciences.mcmaster.ca/econ/ugcm/3/l//lebon/Crowds.pdf

»Miller, J-A. (2017). Política lacaniana. Buenos Aires: Colección Diva.

»Pavlovsky, E. (2001). La ética del cuerpo. Nuevas conversaciones. Buenos Aires: Atuel.

»Sartre, J. P. (1966). El ser y la nada. Buenos Aires: Losada. 